\title{
Plants and their derivatives as potential source in treatment of alcohol withdrawal syndrome and other treatment strategies: A review
}

\author{
G.S. Sri Bharathi, V. Lalitha , P.P. Sethumathi, T. Sivakumar, P P. Selvi*, M. Kavitha** and R. Navin Kumar*** \\ Department of Pharmacology, Nandha College of Pharmacy, Erode 638052, Tamilnadu, India \\ * Department of Cardiology, Nandha College of Physiotherapy, Erode 638052, Tamilnadu, India \\ ** Child Health Nursing, Nandha College of Nursing, Erode 638052, Tamilnadu, India \\ *** Nandha Engineering College, Erode 638052, Tamilnadu, India
}

\section{Article Info}

\section{Article history}

Received 12 October 2021

Revised 7 December 2021

Accepted 10 December 2021

Published Online 30 December 2021

\section{Keywords}

Alcohol withdrawal syndrome

Benzodiazepines

Medicinal plants

Therapeutic effect

\begin{abstract}
Alcohol Withdrawal Syndrome (AWS) is a set of symptoms that develops 24 to $48 \mathrm{~h}$ followed by quitting drinking after a prolonged period of heavy drinking. AWS is mild to severe depending upon the duration and quantity of alcohol intake. Up to $50 \%$ of patients who use alcohol experience withdrawal symptoms. The AWS is primarily mediated by GABA and glutamate receptors. Many plants and plant derivatives are used to relieve the symptoms of alcohol withdrawal. Though, benzodiazepines serve as the first-line drugs in treating AWS, on long-term usage they develop an addiction. This review consists of plants with potential therapeutic effects against AWS, published in the literature from 1999 to 2021 . The review contains plant profiles include information about the botanical name, family, animals, methodology, model, the degree of protection, and the active agents against AWS. The literature review was undertaken by searching databases such as Science Direct, Scopus, PubMed, and Google Scholar for articles using relevant keywords. Fifteen plants and nine plant derivatives were selected based on their potency in treating AWS. Studies have confirmed the effects of these medicinal plants and plant derivatives on alcohol withdrawal syndrome. The effects of these plants may prevent, reduce or treat alcohol withdrawal syndrome and other symptoms associated with it.
\end{abstract}

\section{Introduction}

Alcohol use disorder (AUD) is predicted to impact $18 \%$ of the total population and $5 \%$ of the population on an annual basis. $20 \%$ of adults have emergency room admission due to AWS and the frequency of AWS in patients admitted to intensive care units ranges from $8 \%$ to $40 \%$, resulting in infectious complications and higher fatality rates. Up to $50 \%$ of patients who use alcohol experience withdrawal symptoms (Mirijello et al., 2015).

Alcohol withdrawal (AW) syndrome is a set of symptoms that occurred by an individual cessation of alcohol after a prolonged period of excessive use (National Clinical Guideline Centre, 2010). The AWS is a collection of clinical signs and symptoms that occur in people who are addicted to alcohol. They usually develop 24 to $48 \mathrm{~h}$ after cessation of alcohol drinking or reduction in intake (Sachdeva et al., 2021).The mild symptoms including nausea, vomiting, insomnia, shaky hand, anxiety occur $6 \mathrm{~h}$ after quitting alcohol. The more serious problems such as seizure, confusion, hallucinations, and heavy sweating arise $24 \mathrm{~h}$ after cessation of alcohol. Delirium tremens (a severe dysautonomic and encephalopathic state) and withdrawal seizures, both of which can be fatal occur about 1 to 5\% (Mc Keon et al., 2008). Commonly, the lifethreatening severe symptoms are treated with drugs and also need

Corresponding author: Dr.V. Lalitha
Associate Professor, Department of Pharmacology, Nandha College
of Pharmacy, Erode -638052, Tamil Nadu, India
E-mail: sasiikv@gmail.com
Tel.: +91-9789948682
Copyright $\odot 2021$ Ukaaz Publications. All rights reserved. Email: ukaaz@yahoo.com; Website: www.ukaazpublications.com emergency care. The drugs used to treat AW causes addiction, several side effects including withdrawal reflex. The mild symptoms are not yet treated with drugs, but it makes trouble in regular life. Hence, plant-derived compounds are especially used to treat mild AWS without causing any side effects.

\section{Pathophysiology}

Alcohol is a CNS depressant. The AWS caused by an alteration in $\mathrm{GABA}_{\mathrm{A}}$ and NMDA receptor systems (Carlson et al., 2012). Acute alcohol ingestion causes enhanced GABAergic neurotransmission. Whereas, in chronic alcohol exposure a reduction in number, function, and sensitivity of GABA towards the $\mathrm{GABA}_{\mathrm{A}}$ receptors (down-regulation) is observed. Acute reduction in GABA activity is responsible for AWS (insomnia and hyperreflexia) and it is caused by the cessation of alcohol (Olsen and Liang, 2017). Alcohol use reduced the brain's excitatory neurotransmitters such as a spartate and glutamate acting on both NMDA and non-NMDA receptors (Rao et al., 2015). The AW increases the activation of NMDA receptors resulting in increasing entry of calcium to nerve cells. The stimulation of NMDA receptors is responsible for excitatory activity like tremors, anxiety, and seizures. Although, calcium is required for nerve cell activity, an excess of the chemical in neurons has been linked to cell death or toxicity. Repeated cycles of alcohol drinking and abstinence, on the other hand, may result in calcium-related brain damage (Valenzuela, 1997).

\section{Blood alcohol level}

AWS is diagnosed by physical examination and estimation of blood alcohol level. The blood alcohol level varies according to the 
frequency and quantity of alcohol intake, gender, and body weight. Commonly, females have shown a high blood alcohol level compared to males, both of them consuming the same quantity of alcohol. The physiological effects produced by different blood alcohol levels are shown in Table 1 (Dasgupta, 2017).

Table 1: Blood alcohol levels and their physiological effects

\begin{tabular}{|c|c|}
\hline Blood alcohol level & Effect \\
\hline $10-40 \mathrm{mg} / \mathrm{dl}$ & $\begin{array}{l}\text { Relaxation, mild euphoria, } \\
\text { increased social interaction }\end{array}$ \\
\hline $50-70 \mathrm{mg} / \mathrm{dl}$ & Euphoria, motor impairment \\
\hline $80 \mathrm{mg} / \mathrm{dl}$ & Impairment in driving \\
\hline $80-120 \mathrm{mg} / \mathrm{dl}$ & Emotional swings and depression \\
\hline $120-150 \mathrm{mg} / \mathrm{dl}$ & $\begin{array}{l}\text { Motor function and speech are } \\
\text { all severely affected }\end{array}$ \\
\hline $150-200 \mathrm{mg} / \mathrm{dl}$ & Appear drunk. Visual impairment \\
\hline $200-300 \mathrm{mg} / \mathrm{dl}$ & $\begin{array}{l}\text { Vomiting, symptoms of alcohol } \\
\text { intoxication }\end{array}$ \\
\hline $300-400 \mathrm{mg} / \mathrm{dl}$ & $\begin{array}{l}\text { Severe alcohol intoxication, } \\
\text { total loss of consciousness }\end{array}$ \\
\hline $400-500 \mathrm{mg} / \mathrm{dl}$ & Fatal and may be comatose \\
\hline$>500 \mathrm{mg} / \mathrm{dl}$ & $\begin{array}{l}\text { Highly dangerous. Fatal blood } \\
\text { alcohol level }\end{array}$ \\
\hline
\end{tabular}

The mild symptoms of AWS include autonomic symptoms such as nausea, vomiting, diarrhea, elevated body temperature, elevated blood pressure, tachypnea, and motor symptoms such as tremor, ataxia, seizure, gait disturbances, hyperreflexia (Figure 1). The moderate symptoms of AWS such as anxiety, delusion, and hallucination. The severe symptoms of AWS include awareness symptoms such as insomnia, delirium, agitation, and irritability (Jesse et al., 2017). The alcohol withheld leads to chemical alteration in the brain and causes excessive neuronal activity (Sachdeva et al., 2015).

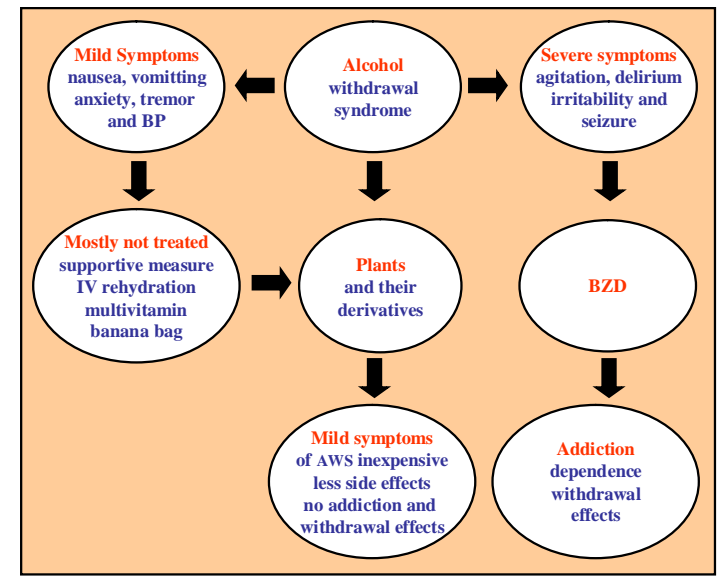

Figure 1: Alcohol withdrawal syndrome and treatment strategies (Jesse et al., 2017).

\section{Alcohol withdrawal assessment}

According to the CLAC-s (clinical institute withdrawal assessment of alcohol scale), the symptoms developed by alcohol withdrawal may be scored as (Knight and Lappalainen, 2017):

\section{Nausea and vomiting}

Score 0: No nausea and vomiting, 1-4: Mild to intermittent nausea with dry heaves, and 5-7: Constant nausea, frequent heaves, and vomiting.

\section{Tremor}

Score 0: No tremor, 1-4: Not visible tremor to moderate tremor, and 5-7: Moderate to severe tremor.

\section{Paroxysmal sweats}

Score 0: No sweat visible, 1-4: Detectable sweating, sweat on the forehead and palm, and 5-7: Drenching sweats.

\section{Anxiety}

Score 0: No anxiety, 1-4: Mild to moderate anxiety, and 5-7: Severe delirium with acute panic states or acute schizophrenia.

\section{Tactile disturbances}

Score 0: None, 1: Very mild itching, burning or numbness, 2: Mild itching, 3: Moderate itching, 4: Moderately severe hallucinations,

5: Severe hallucinations, 6: Extremely severe hallucinations, and

7: Continuous hallucinations.

\section{Agitation}

Score 0: Normal activity, 1-4: Mild to Moderately fidgety and restless, 5-7: Move forth and back.

\section{Auditory and visual disturbances}

Score 0: Not present, 1: Very mild sensitivity, 2-3: Moderate sensitivity, 4: Moderately severe hallucinations, 5: Severe hallucinations, 6: Extremely severe hallucinations, and 7: Continuous hallucinations.

\section{Headache and fullness in head}

Score 0: Not present, 1: Mild, 2: Moderate, 3: Moderately severe, 4: Severe, 5: Very severe, and 6: Extremely severe.

\section{Orientation}

Score 0: Oriented, 1: Cannot do serial additions, 2: Disoriented on a date 3: Disoriented on a date and more than 2 days, and 4: Disoriented for place.

\section{Risk factors and treatment}

The alcohol withdrawal seizure occurred by a reduction in the seizure threshold potential in the early stage of alcohol withdrawal. Acute seizures approximately $90 \%$ occurs within $48 \mathrm{~h}$ of cessation of prolonged alcohol use. The seizures often occur without other symptoms of AWS. AWS especially repeated seizures occurred in $50 \%$ of individuals among $5 \%$ in status epileptics.

Alcohol withdrawal seizures $(<50 \%)$ occurrence rate increased with concurrent risk factors such as brain lesions, prior epilepsy, and use of drugs (Lal, 2005). Benzodiazepines (intravenous diazepam and lorazepam) are, effectively treated against alcohol withdrawal seizures. The benzodiazepine dose is calculated based on average alcohol intake per day. The amount of alcohol consumption is calculated by using the formula (Kattimani and Bharadwaj, 2013): 
Alcohol $($ in $\mathrm{g})=$ Volume of liquor $(\mathrm{ml}) \times 0.008 \times(\%)$ ethanol content in the liquor $(\mathrm{w} / \mathrm{v})$.

In the case of mild to moderate, AWS are treated with supportive therapy including intravenous rehydration, electrolyte supplements, multivitamin, and thiamine especially for Wernicke-Korsakoff syndrome (thiamine deficiency in the brain due to AW) (Muncie et al., 2013). A banana bag is an IV fluid containing vitamins and minerals that are preferably used to treat alcoholics. The bags contain vitamins (thiamine, folic acid), and magnesium sulfate used to correct the chemical alterations in the human body induced by alcohol (Kelsey et al., 2006).

Some of the treatment regimens used in alcohol withdrawal states are fixed-dose regimen (Diazepam $60 \mathrm{mg}$ / Chlordiazepoxide 125 $\mathrm{mg}$ ), loading dose regimen (Diazepam $20 \mathrm{mg}$ ), symptom triggered treatment (CIWA-Ar (Ar-revised version) score 8 or moreChlordiazepoxide), symptom monitored loading dose (Diazepam $20 \mathrm{mg} / 2 \mathrm{~h}$ till CIWA-Ar score becomes 10) and rapid loading with close monitoring (Diazepam) ((Kattimani and Bharadwaj, 2013).

Benzodiazepine withdrawal after prolonged usage may also lead to protracted withdrawal syndromes (Ashton, 1991). However, for severe symptoms scored 5-7 in CIWA, allopathic medicines are the first line choice of drugs. Where as, herbal medicines can be used to treat mild to moderate symptoms scored 1-4 in CIWA categories. Herbal medicines have several advantages such as minimum or no side effects, low cost can be continued for a long period (Vivekanandan et al., 2018; Malik et al., 2020; Lalitha and Sivakumar, 2018; Lalitha et al., 2015), and has no withdrawal effects.

Many plant and plant derivatives are proved in the treatment of alcohol withdrawal syndrome. The main purpose of this article is to highlight several effective medicinal plants used for treating alcohol withdrawal syndrome and other symptoms associated with it.

\section{Materials and Methods}

Publications related to the plants and their derivatives used in the treatment of AWS were collected from databases such as PubMed, Scopus, Science Direct, Wiley, and Springer. Keywords used in this study included "ethanol withdrawal", "medicinal plants", "alcohol withdrawal syndrome", "treatment", and "plant derivatives". Articles published in the period between 1999 and 2021 were included in this review.

Table 2: Plants in treating AWS

\begin{tabular}{|c|c|c|c|c|c|c|}
\hline $\begin{array}{l}\text { Plant name } \\
\text { and family }\end{array}$ & $\begin{array}{l}\text { Part } \\
\text { used }\end{array}$ & $\begin{array}{l}\text { Dose } \\
(\mathrm{mg} / \mathrm{kg})\end{array}$ & $\begin{array}{l}\text { Animal } \\
\text { used }\end{array}$ & $\begin{array}{l}\text { Method of } \\
\text { induction }\end{array}$ & Evaluation & Reference \\
\hline $\begin{array}{l}\text { Bacopa monnieri } \\
\text { Plantaginaceae }\end{array}$ & $\begin{array}{l}\text { Whole } \\
\text { plant }\end{array}$ & $\begin{array}{l}100,200 \\
\text { and } 300 / \mathrm{PO}\end{array}$ & Wistar rats & $\begin{array}{l}\text { A modified liquid } \\
\text { diet with ethanol } \\
7.2 \% \text { for } 21 \text { days }\end{array}$ & $\begin{array}{l}\text { Reverse depression by tail } \\
\text { suspension and forced swim } \\
\text { test). } \\
\text { Hyper locomotor activity } \\
\text { by actophotometer. }\end{array}$ & (Sharma et al., 2018) \\
\hline $\begin{array}{l}\text { Bacopa monnieri } \\
\text { Plantaginaceae }\end{array}$ & $\begin{array}{l}\text { Whole } \\
\text { plant }\end{array}$ & $\begin{array}{l}100,200 \text { and } \\
500 / \mathrm{PO}\end{array}$ & $\begin{array}{l}\text { Male } \\
\text { Wistar rats }\end{array}$ & $\begin{array}{l}\text { A modified liquid } \\
\text { diet with ethanol } \\
9 \% \text { for } 15 \text { days }\end{array}$ & $\begin{array}{l}\text { Anxiety behaviorwas } \\
\text { assessed by elevated plus } \\
\text { maze and light-dark test. } \\
\text { Alcohol markers gabra1, } \\
\text { Gabra4, gabra5 genes of } \\
\text { GABA A }_{\text {A }} \text { receptors. }\end{array}$ & $\begin{array}{l}\text { (Gupta and Sharma, } \\
\text { 2019) }\end{array}$ \\
\hline $\begin{array}{l}\text { Clitoria ternatea } \\
\text { Fabaceae }\end{array}$ & $\begin{array}{l}\text { Aerial } \\
\text { parts }\end{array}$ & $\begin{array}{l}100,200 \text { and } \\
400 / \mathrm{PO}\end{array}$ & $\begin{array}{l}\text { Swiss albino } \\
\text { mice }\end{array}$ & $\begin{array}{l}\text { A modified liquid } \\
\text { diet with ethanol } \\
6.3 \% \text { for } 10 \text { days }\end{array}$ & $\begin{array}{l}\text { Antidepressant activity } \\
\text { by forced swim test. }\end{array}$ & $\begin{array}{l}\text { (Prashant et al., } \\
\text { 2018) }\end{array}$ \\
\hline $\begin{array}{l}\text { Crocus sativus } \\
\text { Iridaceae }\end{array}$ & Stigma & $\begin{array}{l}40,80 \text { and } \\
160 / \mathrm{PO}\end{array}$ & $\begin{array}{l}\text { Male mice } \\
\text { and Male } \\
\text { BALB/c } \\
\text { mice }\end{array}$ & $\begin{array}{l}\text { Ethanol } 2 \mathrm{~g} / \mathrm{kg} \\
(10 \% \mathrm{v} / \mathrm{v}) \text { for } 7 \\
\text { days }\end{array}$ & $\begin{array}{l}\text { Seizure threshold by } \\
\text { PTZ kindling. } \\
\text { Antidepressant activity by } \\
\text { a forced swim and open } \\
\text { field test. }\end{array}$ & $\begin{array}{l}\text { (Shoja et al., 2018; } \\
\text { (Hosseinzadeh et al., } \\
\text { 2004) }\end{array}$ \\
\hline $\begin{array}{l}\text { Hypericumper } \\
\text { foratum } \\
\text { Hypericaceae }\end{array}$ & $\begin{array}{l}\text { Aerial } \\
\text { parts }\end{array}$ & $\begin{array}{l}25,50,100 \\
\text { and } 200 / \mathrm{PO}\end{array}$ & $\begin{array}{l}\text { Male } \\
\text { Wistar rats }\end{array}$ & $\begin{array}{l}\text { A modified liquid } \\
\text { diet with ethanol } \\
7.2 \% \text { for } 15 \text { days. }\end{array}$ & $\begin{array}{l}\text { Decreased locomotor } \\
\text { hyperactivity. } \\
\text { Reduction in the stereo } \\
\text { type behavior. }\end{array}$ & (Coskun et al., 2006) \\
\hline $\begin{array}{l}\text { Pueraria mon- } \\
\text { tana var } \\
\text { Fabaceae }\end{array}$ & Root & $\begin{array}{l}500 \mathrm{mg} / \mathrm{kg} / \\
\text { PO }\end{array}$ & $\begin{array}{l}\text { Female AP } \\
\text { rats }\end{array}$ & $\begin{array}{l}15 \% \text { ethanol for } \\
50 \text { days }\end{array}$ & $\begin{array}{l}\text { Suppressed alcohol intake } \\
\text { and AWS. }\end{array}$ & $\begin{array}{l}\text { (Benlhabib et al., } \\
\text { 2004) }\end{array}$ \\
\hline $\begin{array}{l}\text { Pueraria montana } \\
\text { var Fabaceae }\end{array}$ & Flowers & 200/PO & $\begin{array}{l}\text { Male } \\
\text { Kunming } \\
\text { mice }\end{array}$ & $\begin{array}{l}10 \% \text { ethanol for } \\
28 \text { days }\end{array}$ & $\begin{array}{l}\text { Amelioration of } \\
\text { depression and anxiety. } \\
\text { Brain hippocampal } \\
\text { expression of BDNF. } \\
\text { Plasma CRH, ACTH, and } \\
\text { CORT levels. }\end{array}$ & (Jiang et al., 2021) \\
\hline
\end{tabular}




\begin{tabular}{|c|c|c|c|c|c|c|}
\hline $\begin{array}{l}\text { Mitragyna speciosa } \\
\text { Rubiaceae }\end{array}$ & Leaves & $\begin{array}{l}300, \text { and } \\
500 / \mathrm{PO}\end{array}$ & $\begin{array}{l}\text { Male Swiss } \\
\text { albino mice }\end{array}$ & $\begin{array}{l}\text { A modified liquid } \\
\text { diet with ethanol } \\
7.2 \% \text { for } 30 \text { days }\end{array}$ & $\begin{array}{l}\text { Lowered the behavioral } \\
\text { parameters (rearing, } \\
\text { displacement head weaving, } \\
\text { grooming, lip-smacking, } \\
\text { and scratching). }\end{array}$ & $\begin{array}{l}\text { (Kumarnsit et al., } \\
\text { 2007) }\end{array}$ \\
\hline $\begin{array}{l}\text { Ocimum sanctum } \\
\text { Lamiaceae }\end{array}$ & Leaves & $\begin{array}{l}100,200 \text { and } \\
300 / \mathrm{PO}\end{array}$ & Wistar rats & $\begin{array}{l}\text { A modified liquid } \\
\text { diet with ethanol } \\
7.2 \% \text { for } 21 \text { days }\end{array}$ & $\begin{array}{l}\text { Locomotor hyperactivity } \\
\text { by actophotometer, } \\
\text { anxiety by elevated plus } \\
\text { maze, and light-dark model. }\end{array}$ & (Sharma et al., 2018) \\
\hline $\begin{array}{l}\text { Passiflora incar- } \\
\text { nata } \\
\text { Passifloraceae }\end{array}$ & Plant & 200/PO & $\begin{array}{l}\text { Male Wistar } \\
\text { rats }\end{array}$ & $\begin{array}{l}\text { Ethanol } 4 \mathrm{~g} / \mathrm{kg} \\
(20 \% \mathrm{v} / \mathrm{v}) \text { for } \\
19 \text { days }\end{array}$ & $\begin{array}{l}\text { Nociceptive activity by } \\
\text { Tail flick latency and hot } \\
\text { plate test). }\end{array}$ & (Schunck et al., 2017) \\
\hline $\begin{array}{l}\text { Salsola collina } \\
\text { Chenopodiaceae }\end{array}$ & Plant & 200/PO & $\begin{array}{l}\text { Male Albino } \\
\text { rats } \\
\text { days }\end{array}$ & $\begin{array}{l}\text { Ethanol } 5 \mathrm{~g} / \mathrm{kg} \\
(25 \% \mathrm{v} / \mathrm{v}) \text { for } 5 \\
\text { total lipids level }\end{array}$ & $\begin{array}{l}\text { Phosphatidylethanolamine, } \\
\text { phosphatidylcholine. }\end{array}$ & (Selevich et al., 1999) \\
\hline $\begin{array}{l}\text { Schizandra- } \\
\text { chinensis } \\
\text { Schisandraceae }\end{array}$ & Fruit & $\begin{array}{l}100, \text { and } \\
300 / \mathrm{PO}\end{array}$ & $\begin{array}{l}\text { Male } \\
\text { Sprague } \\
\text { Dawley rats }\end{array}$ & $\begin{array}{l}\text { Ethanol } 3 \mathrm{~g} / \mathrm{kg} \\
(20 \% \mathrm{v} / \mathrm{v}) \text { for } \\
28 \text { days }\end{array}$ & $\begin{array}{l}\text { Anxiety behavior by } \\
\text { Elevated plus maze, } \\
\text { inhibition CORT. } \\
\text { Reduction in norepine- } \\
\text { phrine (NE) and MHPG in } \\
\text { the paraventricular nucleus } \\
\text { of the brain. }\end{array}$ & (Wu et al., 2014)] \\
\hline $\begin{array}{l}\text { Sesbania gran- } \\
\text { diflora } \\
\text { Fabaceae }\end{array}$ & Leaves & $\begin{array}{l}100, \text { and } \\
200 / \mathrm{PO}\end{array}$ & $\begin{array}{l}\text { Female Swiss } \\
\text { albino mice }\end{array}$ & $\begin{array}{l}\text { Ethanol } 2 \mathrm{~g} / \mathrm{kg} \\
(10 \% \mathrm{v} / \mathrm{v}) \text { for } \\
7 \text { days }\end{array}$ & $\begin{array}{l}\text { Antidepressant action by } \\
\text { Forced swim test. }\end{array}$ & $\begin{array}{l}\text { (Sundarrajan and } \\
\text { Velmurugan, 2016) }\end{array}$ \\
\hline $\begin{array}{l}\text { Withania- } \\
\text { somnifera } \\
\text { Solanaceae }\end{array}$ & Root & $50 / \mathrm{PO}$ & $\begin{array}{l}\text { Male Wistar } \\
\text { albino rats }\end{array}$ & $\begin{array}{l}\text { A modified liquid } \\
\text { diet with ethanol } \\
\text { for } 15 \text { days }\end{array}$ & $\begin{array}{l}\text { Antianxiety activity by } \\
\text { Elevated plus-maze. }\end{array}$ & $\begin{array}{l}\text { (Gupta and Rana, } \\
2008 \text { ) }\end{array}$ \\
\hline $\begin{array}{l}\text { Withania- } \\
\text { somnifera } \\
\text { Solanaceae }\end{array}$ & Root & $500 / \mathrm{PO}$ & Albino mice & $\begin{array}{l}\text { Ethanol } 2 \mathrm{~g} / \mathrm{kg} \\
(10 \% \mathrm{v} / \mathrm{v}) \text { for } 7 \\
\text { days }\end{array}$ & $\begin{array}{l}\text { Suppress PTZ kindling } \\
\text { seizure. }\end{array}$ & (Ruby et al., 2012) \\
\hline $\begin{array}{l}\text { Zingiber officinale } \\
\text { Zingiberaceae }\end{array}$ & Rhizome & 200/PO & $\begin{array}{l}\text { Male Wistar } \\
\text { albino rats }\end{array}$ & $\begin{array}{l}\text { Ethanol } 2 \mathrm{~g} / \mathrm{kg} \text { for } \\
42 \text { days }\end{array}$ & $\begin{array}{l}\text { Improved hyperlipidemia } \\
\text { antinephrotoxic effect } \\
\text { (Urea and creatinine level } \\
\text { estimated). }\end{array}$ & (Maralla, 2013) \\
\hline Ziziphi spinosae & Semen & $\begin{array}{l}60, \text { and } \\
180 / \mathrm{PO}\end{array}$ & $\begin{array}{l}\text { Male } \\
\text { Sprague } \\
\text { Dawley } \\
\text { rats }\end{array}$ & $\begin{array}{l}(20 \% v / v) \text { for } 28 \\
\text { days }\end{array}$ & $\begin{array}{l}\text { Ameliorated anxiety } \\
\text { (Elevated plus maze and } \\
\text { open field) by improving } \\
\text { both CRF/CRF receptor } 1 \\
\text { and nociceptin/orphanin } \\
\text { FQ (N/OFQ)/ N/OFQ } \\
\text { peptide receptor (NOP) } \\
\text { transmissions in the central } \\
\text { nucleus of the amygdale. }\end{array}$ & (Li et al., 2019) \\
\hline
\end{tabular}

\section{Medications for AWS}

\subsection{Benzodiazepines}

Benzodiazepines (BZD) including chlordiazepoxide, diazepam, and lorazepam are widely used as first-line medications to suppress the AWS. Long-acting BZD such as chlordiazepoxide, diazepam is superior to other BZD to treat AW delirium and seizures (Witkiewitz et al., 2019). Lorazepam is an intermediate-acting BZD preferably used in patients with liver problems (Girish et al., 2016). Alcohol use and benzodiazepines both act additively on GABA receptors and cause depressant effects and induce suicidal thoughts. Hence, care must be taken when BZD is used to treat AWS (Koh et al., 2021). But, BZD use leads to an increased risk of suicide due to aggression, dementia, respiratory depression, negative withdrawal effects, dependence, and BZD withdrawal syndrome. The BZD overdoses are needed in some cases of AWS, but overdose may cause unconsciousness. Moreover, it has a major risk of abuse and dependence (Guina and Merrill, 2018).

\subsection{Barbiturates}

Barbiturates are less commonly used in the treatment of AW seizures either alone or along with BZDs. Because it causes respiratory 
failure and the need for mechanical ventilation due to its long halflife (Hammond et al., 2017; Martin and Kartz, 2016).

\subsection{Neuroleptics}

Atypical neuroleptics such as risperidone, olanzapine, and quetiapine are used in the treatment of AW hallucinations and delirium (New et al., 2015). Typical neuroleptics such as chlorpromazine, promazine are not used because it causes severe agitation and hypotension. All neuroleptics are only used to calm the patients, but it reduces the seizure threshold and risk of occurrence of seizure and prolongation of QT interval (Kerna, 2020).

\subsection{Anticonvulsants}

NBAC (Non-benzodiazepine anticonvulsants) including carbamazepine is safe and tolerable than BZD in the treatment of AWS (Leggio et al., 2008) and valproic acid has high efficacy and safety to control AW seizure (Farrokh et al., 2021). But, carbamazepine is associated with dizziness, diplopia, ataxia, nausea, and vomiting. Though, anticonvulsants have less abuse potential than benzodiazepines, they do not prevent seizures or delirium tremens (McKeon et al., 2008). Gabapentin was reported to treat mild to moderate AWS, but not act against severe AWS (Hammond et al., 2015).

\section{Plant derivatives in treating AWS}

\subsection{Argan oil}

Argan oil $(10 \mathrm{ml} / \mathrm{kg})$ administration to AWS induced male Wistar rats lower the somatic signs of ethanol withdrawal (stereotyped signs, agitation by irritability to touch, tail stiffness, and abnormal posture and gait, lower anxiety-related behavior (Elevated plus maze and light-dark model) (Figure 2) during abstinence, inhibited oxidative stress and neurodegeneration in the brain by attenuating intermittent ethanol intoxication (IEI) (ElMostafi et al., 2020).

\subsection{Berberine}

Berberine is an isoquinoline alkaloid found in plants. It is found that berberine $(5,10$ and $20 \mathrm{mg} / \mathrm{kg}$, i.p) possess inhibitory effects against ethanol withdrawal (Modified liquid diet with ethanol 10\% for 10 days) induced hyperexcitability signs mediated by its neuromodulatory action in C57BL/6J mice (Bhutada et al., 2011).

\subsection{Curcumin}

The increase in fat and decrease paraoxonase-1(PON-1) activity caused by alcohol consumption and a sedentary lifestyle. A combination of short-term swimming training and curcumin administration was found to increase the activity of PON-1 in male Wistarrats (Azarbayjani et al., 2019).

\subsection{Fluoxetine}

Fluoxetine $(10 \mathrm{mg} / \mathrm{kg})$ attenuated ethanol withdrawal symptoms induced by a modified liquid diet with ethanol $7.2 \%$ for 21 days. The antidepressant activity measures the high-frequency brain wave oscillation and spontaneous motor activity in male Wistarrats. Pretreatment with fluoxetine was attenuated the physical and electrical brain wave activities induced by AW (Cheaha et al., 2014).

\subsection{Fucoidan}

Fucoidan $(300 \mathrm{mg} / \mathrm{kg})$, a polysaccharide component in brown seaweeds when administered to alcohol withdrawal (15\% ethanol for 5 days) C57BL/6J mice, regulated the gut flora of mice exposed to alcohol and reduced endotoxemia. The fucoidan down-regulated the TLR4/MyD88/NF- $\kappa$ B p65 pathway blocks alcohol-induced microglial cell activation, inflammation in the brain and protect against depression-like behaviors induced by alcohol withdrawal (Sucrose preference test, forced swim test, open field test, and Ymaze test) of mice (Xue et al., 2021).

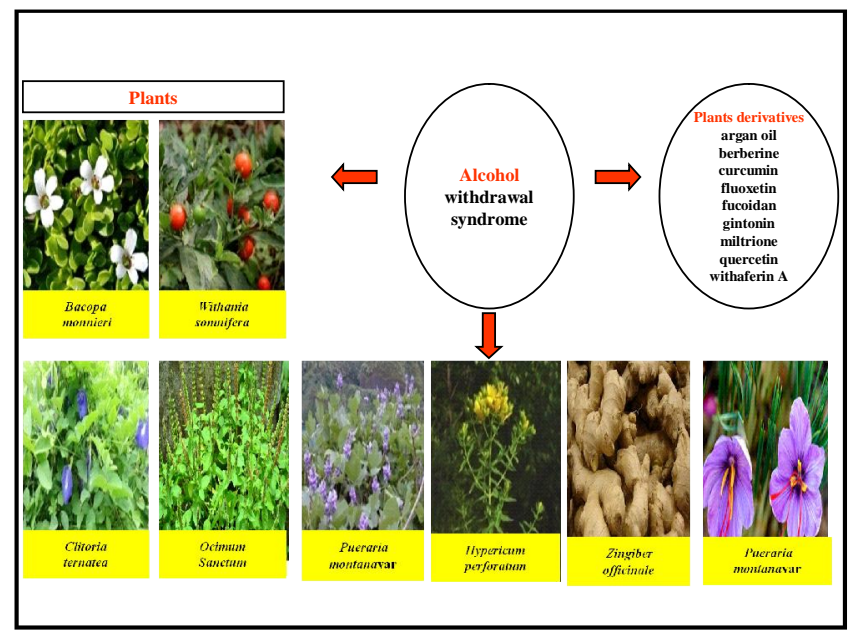

Figure 2: Plant and their derivatives used for alcohol withdrawal syndrome.

\subsection{Gintonin}

Gintonin is isolated from Panax ginseng. It is a lysophosphatidic acid (LPA) receptor-ligand gintonin $(100 \mathrm{mg} / \mathrm{kg})$ to protect against the depressive-like behavior induced by (Forced swim test and tail suspension test) AW (6\% ethanol for 14 days) in C57BL/6 mice. Gintonin elevated the plasma 5-HT levels (Kim et al., 2017).

\subsection{Miltrione}

Miltrione is isolated from the root of the Salvia miltiorrhiza. Miltrione binds with benzodiazepine receptors and partially blocked the increase in the mRNA in a 4 subunit of GABA receptor induced by AW in cultured brain hippocampal cells of Male SD rats (Mostallino et al., 2004).

\subsection{Quercetin}

Quercetin is a plant polyphenolic compound isolated in the various plant kingdom (Das and Gezici, 2018; Gezici et al., 2020). Quercetin ( 25 and $50 \mathrm{mg} / \mathrm{kg} / \mathrm{PO}$ ) on administration for the treatment of ethanol withdrawal syndrome ( $2 \mathrm{~g} / \mathrm{kg}$ ethanol for 6 days) in albino mice, decreased the hyper locomotor activity (Actophotometer) and anxiety (Mirrored chamber test) and was also found to suppress PTZ kindling seizure (Joshi et al., 2005; Lalitha et al., 2021).

\subsection{Withaferin A}

Withaferin A is a steroidal lactone isolated from the Withania somnifera plant (Khare and Naharwar, 2020; Jinukuti and Giri, 2015). Withaferin A (10 and $20 \mathrm{mg} / \mathrm{kg}$, IP) when administered during the alcohol dependence phase from day 15-21 was found to prevent the ethanol withdrawal (modified liquid diet with ethanol $7.2 \%$ for 14 days) induced elevated scores of somatic behaviors (grooming, sniffing, genital licking, head weaving, gnawing, scratching, chewing, 
and body shake), hyperlocomotion (Actophotometer), depressive behavior (Forced swim test), and anxiety (Elevated plus maze) in SD rats. It also attenuated the elevated plasma corticosterone and ACTH levels in ethanol-withdrawn rats (Nandkishor et al., 2018).

\section{Discussion}

Alcohol withdrawal syndrome is a set of distressing mental and physical symptoms that arise when you stop drinking alcohol. The symptoms range from mild tremors to convulsions and hallucinations (Weaver, 2015). The GABA (inhibitory neurotransmitter) and glutamate (excitatory neurotransmitter) are found to play a major role in alcohol withdrawal syndrome (Bayard et al., 2004). Benzodiazepines are considered as the gold-standard treatment for AWS, but research specifies that diazepam poses the potential hazard of dependence (Ennaceur et al., 2010). This review compiles the description and effectiveness of some plant and plant derivatives in an alcohol withdrawal syndrome. A modified liquid diet with ethanol-induced AWS was found to be the most common and preferred method for inducing alcohol withdrawal syndrome in animals. This modified liquid diet includes cow milk $925 \mathrm{ml}+25$ $75 \mathrm{ml}$ ethanol (96.5\% ethyl acetate) + Vitamin A $5000 \mathrm{IU}+$ Sucrose $17 \mathrm{~g}$ or nutritional source. $7.2 \%$ and $10 \%$ ethanol are the preferred choice of concentration for administration. Mostly male Wistar albino rats were preferred over the female (some studies were carried out in females and both sexes). A female alcohol-preferring rat transgenic animalmodel and C57BL/6 transgenic mouse that is specific to alcohol withdrawal syndrome was also used. More plants from the Fabaceae family are found to be effective against AWS. These plants and plant derivatives are found to either suppress the behavioral symptoms of AWS or alter the biochemical parameters that are involved in the ethanol withdrawal syndrome.

\section{Conclusion}

Currently, mild to moderate alcohol withdrawal symptoms are not treated with medications because of their side effects. The life threatened severe symptoms only treated with drugs. The plant and plant derived components especially used to treat mild to moderate AWS. Prolong use of plant medication does not produce addiction, withdrawal symptoms like benzodiazepines. The plants are cheap, easily available, and cause very less side effects.

Plants provide natural anxiolytic, antioxidant activity and serve as effective herbal medicines, in part due to their active compounds, such as flavonoids, tannins, phenolics, and alkaloids that improve the performance of the central nervous system and other peripheral organs involved in an alcohol withdrawal syndrome.More researches are needed to separate the active constituents of plants and molecular interactions of their compounds for analysis of their therapeutic and prophylactic properties against AWS.

\section{Acknowledgments}

The authors would like to thank the management of Nandha College of Pharmacy in Erode for their support, cooperation, and helpful recommendations, as well as for providing the best facilities possible during this research.

\section{Conflict of interest}

The authors declare no conflicts of interest relevant to this article.

\section{References}

Ashton, H. (1991). Protracted withdrawal syndromes from benzodiazepines. Journal of Substance Abuse Treatment, 8(1-2):19-28.

Azarbayjani, M.A.; Peeri, M. and Mateen Homaei, H. (2019). The effect of shortterm training and curcumin on the paraoxonase-1 activity after alcohol withdrawal in male Wistar rats. Ebnesina, 20(4):11-18.

Bayard, M.; Mcintyre, J.; Hill, K. and Woodside, J. (2004). Alcohol withdrawal syndrome. American Family Physician, 69(6):1443-1450.

Benlhabib, E.; Baker, J.I.; Keyler, D.E. and Singh, A.K. (2004). Kudzu root extract suppresses voluntary alcohol intake and alcohol withdrawal symptoms in $\mathrm{P}$ rats receiving free access to water and alcohol. Journal of Medicinal Food, 7(2):168-179.

Bhutada, P.; Mundhada, Y.; Bansod, K.; Hiware, R.; Rathod, S.; Dixit, P. and Mundhada, D. (2011). Berberine protects C57BL/6J mice against ethanol withdrawal induced hyperexcitability. Phytotherapy Research, 25(2):302-307.

Carlson, R. W.; Kumar, N. N.; Wong-Mckinstry, E.; Ayyagari, S.; Puri, N.; Jackson, F. K. and Shashikumar, S. (2012). Alcohol withdrawal syndrome. Critical Care Clinics, 28(4):549-585.

Cheaha, D.; Sawangjaroen, K. and Kumarnsit, E. (2014). Characterization of fluoxetine effects on ethanol withdrawal-induced cortical hyperexcitability by EEG spectral power in rats. Neuropharmacology, 77:4956

Coskun, I.; Tayfun Uzbay, I.; Ozturk, N. and Ozturk, Y. (2006). Attenuation of ethanol withdrawal syndrome by extract of Hypericum perforatum in Wistar rats. Fundamental and Clinical Pharmacology, 20(5):481488 .

Das, K.; and Gezici, S. (2018). Secondary plant metabolites, their separation and identification, and role in human disease prevention. Ann. of Phytomedicine., 7:13-24.

Dasgupta, A. (2017). Alcohol, drugs, genes and the clinical laboratory. Science Direct.

El Mostafi, H.; Elhessni, A.; Touil, T.; Ouichou, A.; Laaziz, A.; Doumar, H. and Mesfioui, A. (2020). Argan oil supplementation attenuates voluntary ethanol consumption and withdrawal syndrome promoted by adolescent intermittent ethanol in rat. Alcohol, 87:39-50.

Ennaceur, A.; Michalikova, S.; van Rensburg, R. and Chazot, P.L. (2010). Tolerance, sensitization and dependence to diazepam in $\mathrm{Balb} / \mathrm{c}$ mice exposed to a novel open space anxiety test. Behavioural Brain Research, 209(1):154-164.

Farrokh, S.; Roels, C.; Owusu, K.A.; Nelson, S.E. and Cook, A.M. (2021). Alcohol withdrawal syndrome in Neurocritical care unit: Assessment and treatment challenges. Neurocritical Care, 34(2):593-607.

Gezici, S.; Koçum, D.; Yayla, F.; Sekeroglu, N. and Khan, A.A. (2020). Screening for in vitro antioxidant activities, polyphenolic contents and neuroprotective potentials of Clinopodium serpyllifolium subsp. serpyllifolium endemic to Turkey. Ann. of Phytomedicine., 9(1):181-186.

Girish, K.; Reddy, K.V.; Pandit, L.V.; Pundarikaksha, H.P.; Vijendra, R.; Vasundara, K. and Shruthi, R. (2016). A randomized, open-label, standard controlled, parallel group study of efficacy and safety of baclofen, and chlordiazepoxide in uncomplicated alcohol withdrawal syndrome. Biomedical Journal, 39(1):72-80.

Guina, J. and Merrill, B. (2018). Benzodiazepines I: Upping the care on downers: The evidence of risks, benefits and alternatives. Journal of Clinical Medicine, 7(2):17. 
Gupta, G.L. and Rana, A. C. (2008). Effect of Withania somnifera Dunal in ethanol-induced anxiolysis and withdrawal anxiety in rats. Indian Journal of Experimental Biology, 46(6):470-475.

Gupta, G.L. and Sharma, L. (2019). Bacopa monnieri abrogates alcoho abstinence-induced anxiety-like behavior by regulating biochemical and Gabra1, Gabra4, Gabra5 gene expression of GABAA receptor signaling pathway in rats. Biomedicine and Pharmacotherapy, 111:1417-1428

Hammond, C.J.; Niciu, M.J.; Drew, S. and Arias, A.J. (2015). Anticonvulsants for the treatment of alcohol withdrawal syndrome and alcohol use disorders. CNS Drugs, 29(4):293-311.

Hammond, D.A.; Rowe, J.M.; Wong, A.; Wiley, T.L.; Lee, K.C. and Kane-Gill, S.L. (2017). Patient outcomes associated with phenobarbital use with or without benzodiazepines for alcohol withdrawal syndrome: A systematic review. Hospital Pharmacy, 52(9):607-616.

Hosseinzadeh, H.; Karimi, G.H. and Niapoor, M. (2004). Antidepressant effect of Crocus sativus stigma extracts and its constituents, crocin and safranal, in mice. Journal of Medicinal Plants, 3(11):48-58.

Jesse, S.; Bråthen, G.; Ferrara, M.; Keindl, M.; Ben Menachem, E.; Tanasescu, R. and Ludolph, A.C. (2017). Alcohol withdrawal syndrome: mechanisms, manifestations and management. Acta Neurologica Scandinavica, 135(1):4-16

Jiang, B.; Yang, W.; Xiu, Z; Zhang, L.; Ren, X.; Wang, L. and Asakawa, T. (2021). An in vivo explorative study to observe the protective effects of Puerariae flos extract on chronic ethanol exposure and withdrawal male mice. Biomedicine and Pharmacotherapy, 137:111306.

Jinukuti, M.G. and Giri, A. (2015). Anticancer activity of acetone and methanol extracts of Terminalia chebula Retz and Withania somnifera (Linn.) Dunal on HeLa cell line. Ann. of Phytomedicine., 4(2):88-92.

Joshi, D.; Naidu, P.S.; Singh, A. and Kulkarni, S.K. (2005). Protective effect of quercetin on alcohol abstinence-induced anxiety and convulsions. Journal of Medicinal Food, 8(3):392-396.

Kattimani, S. and Bharadwaj, B. (2013). Clinical management of alcoho withdrawal: A systematic review. Industrial Psychiatry Journal, 22(2):100-108.

Kelsey, J.E.; Newport, D.J. and Nemeroff, C.B. (2006). Principles of psychopharmacology for mental health professionals, Wiley-Liss., pp:196-197.

Kerna, N.A. (2020). Recognizing the PPAT of AWS in the AUD-Patient: An imperative for the early screening, identification, and treatment of alcohol withdrawal syndrome in alcohol use disorder patients in emergency and intensive care settings by distinguishing AWS pathophysiology, progression, assessment, and treatment more directly. EC Nursing and Healthcare, 2:3-8.

Khare, C.P. and Naharwar, A.V. (2020). Ashwagandha (Withania somnifera (L.) Dunal): A scientific review with respect to Ayurvedic perspectives. Ann. of Phytomedicine., 9(2):134-141.

Kim, H.J.; Park, S.D.; Lee, R.M.; Lee, B.H.; Choi, S.H.; Hwang, S.H. and Nah, S.Y. (2017). Gintonin attenuates depressive-like behaviors associated with alcohol withdrawal in mice. Journal of Affective Disorders, 215:2329.

Knight, E. and Lappalainen, L. (2017). Clinical institute withdrawal assessment for alcohol-revised might be an unreliable tool in the management of alcohol withdrawal. Canadian Family Physician, 63(9):691.
Koh, J.J.K.; Malczewska, M.; Doyle, M.M. and Moe, J. (2021). Prevention of alcohol withdrawal seizure recurrence and treatment of other alcohol withdrawal symptoms in the emergency department: A rapid review. BMC Emergency Medicine, 21(1):1-12.

Kumarnsit, E.; Keawpradub, N. and Nuankaew, W. (2007). Effect of Mitragyna speciosa aqueous extract on ethanol withdrawal symptoms in mice. Fitoterapia, 78(3):182-185.

Lal, R. (2005). Pharmacotherapy of substance use disorders. In: Lal R, editor. Substance Use Disorders: Manual for Physicians. New Delhi: National Drug Dependence Treatment Center, All India Institute of Medical Sciences.

Lalitha, V.; Mejo, C. K.; Sengottuvel, S. and Sivakumar, T.(2015). Antidiabetic and antioxidant activity of resveratrol and vitamin- $\mathrm{C}$ combination on streptozotocin induced diabetic rats. International Journal of Pharmacy and Pharmaceutical Sciences, 7(9):455-458.

Lalitha, V.; Roxanne, G. M. and Sivakumar, T. (2021). Evaluation of the laxative activity saponin enriched hydroethanolic pericarp extract of Sapindus emarginatus in animal models. Current Bioactive Compounds, 17(6):7-13

Lalitha, V. and Sivakumar, T.(2018). Effect of silymarin on intestinal alkaline phosphatase level in a rat model of type 2 diabetes mellitus: Streptozotocin and high-fat diet treated wistar rats. Asian J. Pharm. Clin. Res., 11(11):201304-306.

Leggio, L.; Kenna, G.A. and Swift, R.M. (2008). New developments for the pharmacological treatment of alcohol withdrawal syndrome. A focus on non-benzodiazepine GABAergic medications. Progress in NeuroPsychopharmacology and Biological Psychiatry, 32(5):1106-1117.

Li, L.B.; Kim, Y.W.; Wang, Y.H.; Bai, L.; Zhu, X.D.; Zhao, Z.L. and Zhao, R.J. (2019). Methanol extract of semen Ziziphi spinosae attenuates ethanol withdrawal anxiety by improving neuropeptide signaling in the central amygdala. BMC Complementary and Alternative Medicine, 19(1): $1-15$.

Malik, T.; Madan, V.K.; and Prakash, R. (2020). Herbs that heal: Floristic boon to the natural healthcare system. Ann. of Phytomedicine., 9(2):614.

Maralla, S. (2013). Effect of ginger extract consumption on renal function during ethanol withdrawal induced-stress. International Journal of Innovative Research in Science, Engineering and Technology, 2(11):6412-6418.

Martin, K. and Katz, A. (2016). The role of barbiturates for alcohol withdrawal syndrome. Psychosomatics, 57(4):341-347.

McKeon, A.; Frye, M.A. and Delanty, N. (2008). The alcohol withdrawal syndrome. Journal of Neurology, Neurosurgery and Psychiatry, 79(8):854-862.

Mirijello, A.;Angelo, C.; Ferrulli, A.; Vassallo, G.; Antonelli, M.; Caputo, F. and Addolorato, G. (2015). Identification and management of alcohol withdrawal syndrome. Drugs, 75(4):353-365.

Mostallino, M.C.; Mascia, M.P.; Pisu, M.G.; Busonero, F.; Talani, G. and Biggio, G. (2004). Inhibition by miltirone of up-regulation of GABAA receptor á4 subunit mRNA by ethanol withdrawal in hippocampal neurons. European Journal of Pharmacology, 494(2-3):83-90.

Muncie, H.L.; Yasinian, Y. and Oge, L.K. (2013). Outpatient management of alcohol withdrawal syndrome. American Family Physician, 88(9):589-595.

Nandkishor, R.K.; Ankit, K.; Rupali, G.; Shubham, N.R.; Dinesh, Y.G.; Milind, J.U. and Brijesh G.T. (2018). Withaferin A attenuates alcohol abstinence signs in rats, Phamacognosy Journal, 10(6):1190-1195. 
National Clinical Guideline Centre (2010). Acute alcohol withdrawal, alcohol use disorders: Diagnosis and clinical management of alcohol-related physical complications (No. 100 ed.). London: Royal College of Physicians (UK). Archived from the original on 31 January 2014. Retrieved 21 October 2016.

New, A.M.; Nelson, S. and Leung, J.G. (2015). Psychiatric emergencies in the intensive care unit. AACN Advanced Critical Care, 26(4):285-293.

Olsen, R.W. and Liang, J. (2017). Role of GABA A receptors in alcohol use disorders suggested by chronic intermittent ethanol (CIE) rodent model. Molecular Brain, 10(1):1-20.

Prashant, D.M.; Sandeep, P.G.; Pallavi, R.K.; Pramila, S. and Kishore G. (2018), Evaluation of ethanolic extract of Clitoria ternatea in ethanol withdrawal-induced depression, Pharmacology Online, 1:164-175.

Rao, P.S.S.; Bell, R.L.; Engleman, E.A. and Sari, Y. (2015). Targeting glutamate uptake to treat alcohol use disorders. Frontiers in neuroscience, 9: 144 .

Ruby, B.; Benson, M.K.; Kumar, E.P.; Sudha, S. and Wilking, J.E. (2012). Evaluation of Ashwagandha in alcohol withdrawal syndrome. Asian Pacific Journal of Tropical Disease, 2:856-860.

Sachdeva, A.; Choudhary, M. and Chandra, M. (2015). Alcohol withdrawal syndrome: Benzodiazepines and beyond. Journal of Clinical and Diagnostic Research: JCDR, 9(9):VE01.

Sachdeva,A.; Kumar, V.; Rizvi, S.A.A.; Khullar, S.; Abidi, S.S.A. and Das, A. (2021). Pattern of alcohol withdrawal syndrome and its clinical correlates. Biomedicine, 41(2):278-282.

Schunck, R.V.A.; Macedo, I.C.; Laste, G.; de Souza, A.; Valle, M.T.C.; Salomón, J.L. and Leal, M.B. (2017). Standardized Passiflora incarnata L. extract revert the analgesia induced by alcohol withdrawal in rats. Phytotherapy Research, 31(8):1199-1208.

Selevich, M.I.; Lelevich, V.V. and Razvadovskii Y.E. (1999). Effects of saltwort plants on blood plasma lipids in rats during chronic alcohol intoxication and after ethanol withdrawal, Bulletin of Experimental Biology and Medicine, 127(6):607-609.
Sharma, L.; Sharma, A.; Gupta, G.L. and Bisht, G.S. (2018). Pharmacological evaluation of Bacopa monnieri extract against depressive like behavior induced by ethanol withdrawal in rats. Pharmacognosy Journal, 10(6):48-53.

Sharma, L.; Sharma, A.; Gupta, G. L. and Bisht, G.S. (2018). Protective effect of Ocimum sanctum Linn. leaf extract on ethanol withdrawal syndrome in Wistar rats. Asian Pacific Journal of Tropical Medicine, 11(8):467-472.

Shoja, M.; Mehri, S.; Amin, B.; Askari, V.R. and Hosseinzadeh, H. (2018). The prophylactic and therapeutic effects of saffron extract and crocin on ethanol withdrawal syndrome in mice. Journal of Pharmacopuncture, 21(4):277.

Sundarrajan, T. and Velmurugan, V. (2016). Pharmacological evaluation of Sesbania grandiflora Linn in alcohol withdrawal syndrome in rats. International Journal of Pharmaceutical Sciences Review and Research, 38(1):185-188.

Valenzuela, C.F. (1997). Alcohol and neurotransmitter interactions. Alcohol Health and Research World, 21(2):144-148.

Vivekanandan, L.; Sheik, H.; Singaravel, S. and Thangavel, S. (2018). Ameliorative effect of silymarin against linezolid-induced hepatotoxicity in methicillin-resistant Staphylococcus aureus (MRSA) infected Wistar rats. Biomedicine and Pharmacotherapy, 108:1303-1312.

Weaver, M.F. (2015). Focus: addiction: prescription sedative misuse and abuse. The Yale Journal of Biology and Medicine, 88(3):247.

Witkiewitz, K.; Litten, R.Z. and Leggio, L. (2019). Advances in the science and treatment of alcohol use disorder. Science Advances, 5(9):4043.

Wu, Y.; Zhao, Z.; Yang, Y.; Yang, X.; Jang, E.Y.; Schilaty, N.D. and Zhao, R. (2014). Effects of the aqueous extract of Schizandra chinensis fruit on ethanol withdrawal-induced anxiety in rats. Chinese Medical Journal, 127(10):1935-1940.

Xue, M.; Teng, X.; Liang, H.; Zhao, J.; Jiang, Y.; Qiu, X. and Qin, Y. (2021). Neuroprotective effect of fucoidan by regulating gut-microbiotabrain axis in alcohol withdrawal mice. Journal of Functional Foods, 86: 104726 . 